\title{
Structural basis of contraction in vitreal fibrous membranes
}

\author{
I. GRIERSON AND A. H. S. RAHI
}

From the Department of Pathology, Institute of Ophthalmology, 17/25 Cayton Street, London EC1V 9AT

\begin{abstract}
SUMMARY A combined ultrastructural and immunofluorescent study was conducted on experimentally induced fibrous membranes in the vitreous of adult rabbits. Autochthonous tissue cultured fibroblasts were injected into the mid-vitreous of one eye of each of 25 rabbits. The animals were monitored routinely with an ophthalmoscope and slit-lamp and were killed at various time periods between 5 minutes and 6 months. Appropriate tissue was taken for light microscopy, transmission electron microscopy, scanning electron microscopy, and indirect immunofluorescence. With this model we were able to show that the contractile elements in fibrous membranes are probably modified fibroblasts called myofibroblasts which are most abundant 3 to 6 weeks after injection. This is the time when retinal detachment usually occurs. It is our impression that, as traction membranes develop, there is not so much an increase in the contractile elements of the constituent cells as a rearrangement of the existing cytoplasmic microfilaments into compact highly organised bundles called stress cables. The behaviour and ultrastructural characteristics of intravitreal fibroblasts compare with the action of fibroblasts in the healing of wounds.
\end{abstract}

Experimental vitreal fibrous membranes have been produced in the rabbit eye by the injection of autochthonous (autologous) cultured skin fibroblasts into the centre of the vitreous cavity. ${ }^{1-3}$ These membranes are contractile and can produce traction detachments of the retina. Indeed in their preliminary study Grierson and Forrester ${ }^{3}$ found that of the 7 animals which were followed up for at least 4 weeks 5 developed detachments. More extensive investigations have been conducted by Algvere and Kock ${ }^{1}$ and Sugita $\mathrm{et} \mathrm{al.}{ }^{2}$ in whose experimental series detachment developed in $50 \%$ and $55 \%$ of the injected eyes respectively.

It would seem, then, that the rabbit model is a useful means of studying the basic mechanisms involved in the process of membrane contraction and subsequent retinal detachment. The experimental fibrous membranes produced in the rabbit appear to have a similar biological behaviour to those found in human pathological specimens. Nonvascular fibrous membranes develop in association with the vascular proliferations which characterise diabetic retinopathy, and undoubtedly they contribute to the progressive visual disability. ${ }^{4}$ Retinal detachment is a common late complication following trauma to the posterior globe of the eye, and the detachments occur

Correspondence to Dr I. Grierson. when sheets of scar tissue form within the vitreal cavity. ${ }^{5-8}$ Further serious visual complications can ensue in eyes with rhegmatogenous retinal detachment due to the action of vitreal fibrous tissue in exacerbating the initial detachment.9

Clearly with a better understanding of the nature of membrane contraction and the precise pathogenetic events which take place during the formation of fibrous membranes decisions regarding the best time for surgical intervention will have a less empirical basis. Also the possibility of pharmacological inhibition of membrane development or contraction will be brought a step nearer.

In the present investigation ultrastructural and immunofluorescent techniques were used to study the development of scar tissue in the rabbit vitreous and to study the basis of contraction in the developing membranes. Comparisons were made between fibroblast activity in wound healing of the skin and membrane formation in the vitreous.

\section{Materials and methods}

\section{EXPERIMENTAL PROCEDURES}

Skin biopsies were taken from the backs of 25 albino rabbits which weighed between 1.5 and $3.0 \mathrm{~kg}$. The hair in the area to be biopsied was closely cropped and then cleaned with $70 \%$ alcohol. Local anaesthesia 
was induced by the intradermal injection of lignocaine hydrochloride, and thereafter a segment of skin was removed and sliced into 3 or 4 blocks which were approximately $1 \mathrm{~mm}$ wide. The blocks were then introduced into Falcon flasks and fixed into position with a double layer of chick plasma clot. ${ }^{10}$ These flasks were kept in an incubator at $37-38^{\circ} \mathrm{C}$, fed twice every week with tissue culture medium, ${ }^{11}$ and maintained in an environment of $5 \% \mathrm{CO}_{2}$ and air. After approximately 2 weeks in primary culture a monolayer of fibroblasts had formed and the clot had split and disintegrated. The fibroblasts were subcultured for a further 2 to 3 weeks until there was a sufficient crop of cells for for intravitreal injection. To harvest the cells the monolayer was dissociated with a solution of $0.25 \%$ trypsin in phosphate-buffered saline or scraped off with a rubber 'policeman' and then collected in a sterile syringe. The cells were finally washed 3 or 4 times in isotonic phosphate-buffered saline prior to being centrifuged at $1000 \mathrm{rpm}$ for 6 minutes.

The cells were resuspended in phosphate-buffered salt solution, cell frequency was checked with a haemocytometer, and $0.2 \mathrm{ml}$ of fluid containing 400000 to 1000000 fibroblasts was taken up into a syringe. A second sample of cells was vitally stained with trypan blue, and the frequency of dead and damaged cells in the fibroblast population was checked.

At this time the appropriate rabbit was anaes-

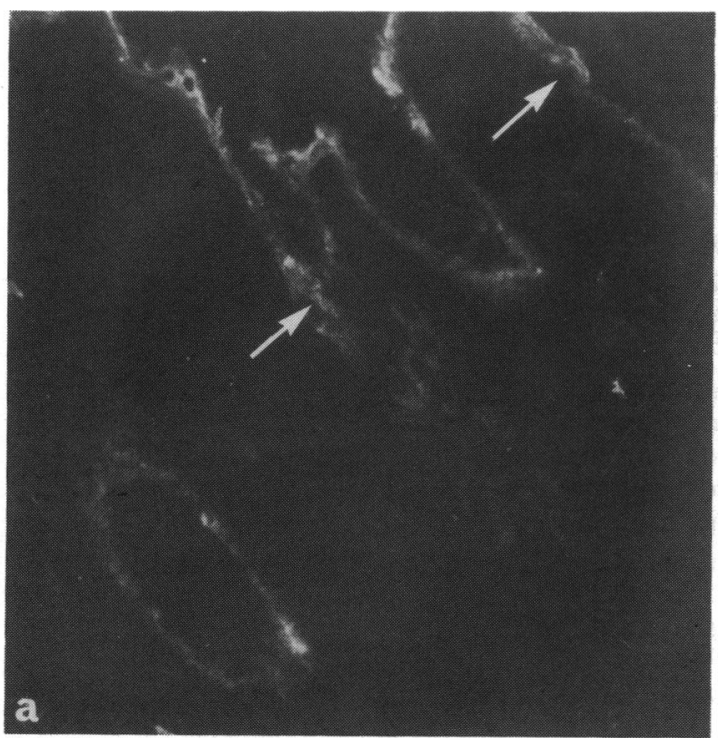

thetised with intravenous sodium pentobarbitone ( $30 \mathrm{mg}$ per $\mathrm{kg}$ body weight) and one eye softened by the withdrawal of $0.2 \mathrm{ml}$ of aqueous humour (see Forrester and Grierson ${ }^{12}$ ). Subsequently the $0.2 \mathrm{ml}$ of suspended fibroblasts were injected into the central vitreous cavity via the pars plana. The whole procedure was carried out under ophthalmoscopic control. Routine examination included ophthalmoscopic and slit-lamp observation of the experimental eyes for the duration of the study. In this way a photographic record of the key changes during the development of the vitreal membranes and the subsequent retinal detachment (if it took place) was available for each animal.

\section{HISTOLOGICAL PROCEDURES}

The animals were killed with an intravenous overdose of sodium pentobarbitone $5 \mathrm{~min}, 2 \mathrm{~h}, 4 \mathrm{~h}, 1$ day, 2 days, 3 days, 6 days, 2 weeks, 3 weeks, 6 weeks, 10 weeks, 3 months, and 6 months after the intravitreal injection of fibroblasts. The eyes were opened in the appropriate plane depending on the position of the fibroblasts or the developing membranes and fixed in $3 \%$ glutaraldehyde solution in cacodylate buffer. After macroscopic photography and a minimum of 4 hours in primary fixative samples of retina, optic nerve, vitreous, lens, ciliary body, and limbus were dissected out for post-fixation in $1 \%$ osmium tetroxide. Thereafter the segments were dehydrated in

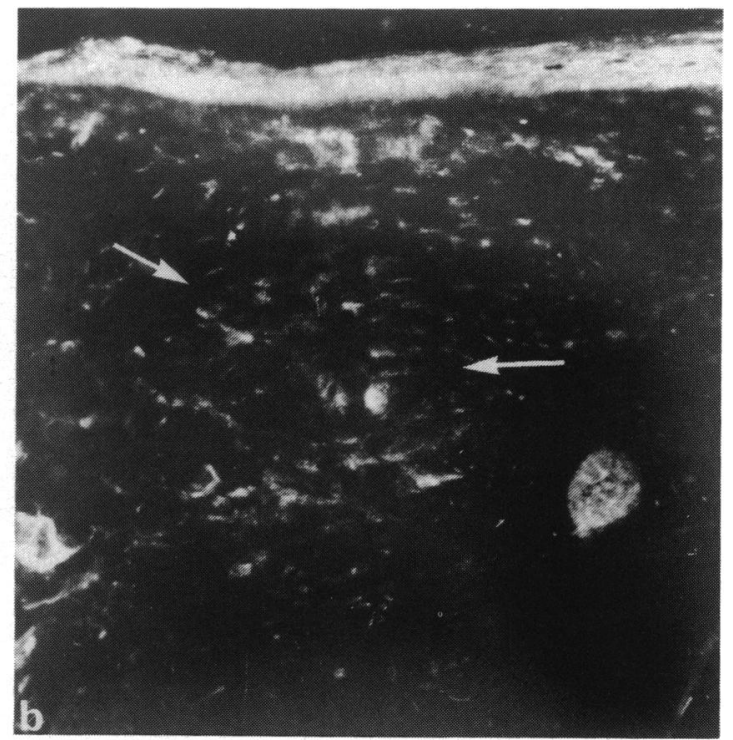

Fig. 1 Indirect immunofluorescent staining with sera rich in 'smooth-muscle' antibody. (a) A frozen section from normal skin with positive staining in the epidermis (arrows) but not in the dermis. (b) A frozen section from a 14-day scar: there is strong fluorescence in the dermis (arrows) corresponding to the presence of activated fibroblasts. $(\times 80)$. 


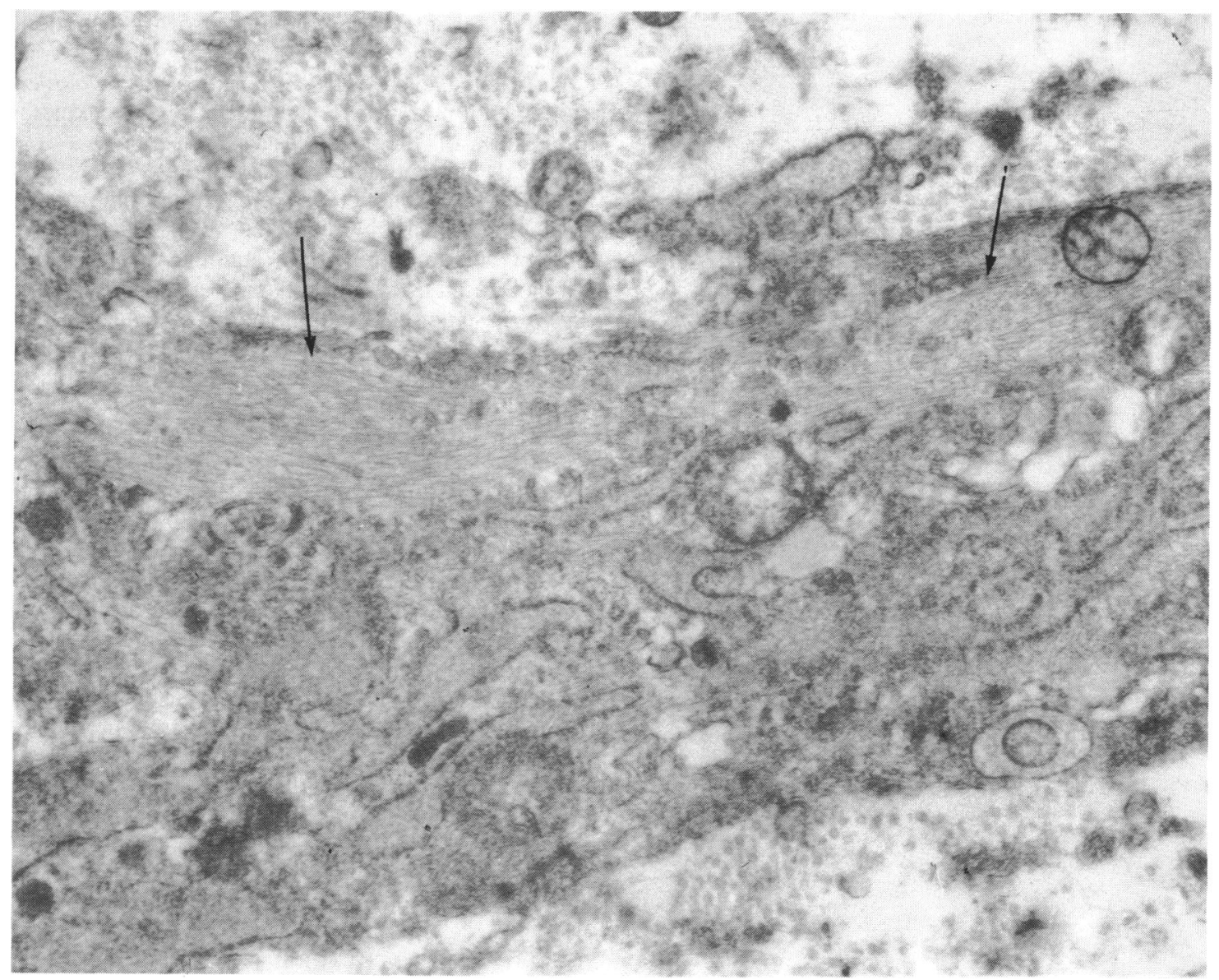

Fig. 2 An electron micrograph which shows part of a fibroblast from a 14-day scar. There is a thick bundle of 6 to $7 \mathrm{~nm}$ diameter microfilaments within the cytoplasm (arrows). (Uranyl acetate/lead citrate stained section; $\times 30000$ ).

ascending grades of ethanol. Some tissue segments were dried in a critical point drier (Polaron), mounted on standard stubs, coated with gold in a sputter coater (Polaron), and studied in a Cambridge S4-10 scanning electron microscope. However, after dehydration in ethanol most of the tissue was cleared in propylene oxide and embedded in Araldite. Sections were cut on an LKB Ultrotome III or a Huxley microtome and viewed in a JEOL $100 \mathrm{C}$ electron microscope.

Some of the established monolayers of skin fibroblasts not needed for intravitreal injection were fixed and processed for electron microscopy in the manner described above. Other monolayers were fixed in $10 \%$ formol basic-salt solution and stained with periodic acid Schiff and haematoxylin.

Segments of the scar tissue which formed at the sites of the skin biopsies were taken from 3 days to 5 weeks following the initial wound. These were either processed conventionally for wax histology or for transmission electron microscopy.

\section{IMMUNOFLUORESCENT STUDIES}

For this part of the investigation monolayers of cultured fibroblasts, early fibroblast aggregates from the vitreous, and mature membranes of various ages were washed in isotonic saline and fixed in acetone. When normal skin, skin scar tissue, and whole globes were required for examination, they were first frozen and then sectioned on a cryostat.

Blood from patients with chronic uveitis or intraocular melanoma which had high titres (that is, $1 / 160$ or better) of antibodies to smooth muscle proteins, particularly actin ${ }^{13-15}$ served as the source of antiserum to localised contractile cytoplasmic proteins. Reactivity and specificities were assessed by detailed examination of various tissues from a rat-for 


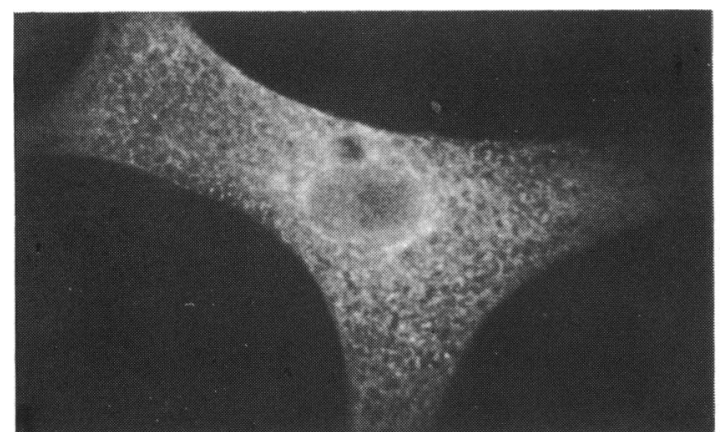

Fig. 3 Indirect immunofluorescent staining with sera rich in 'smooth-muscle' antibody of a fibroblast at the growing edge of a culture. $(\times 816)$.

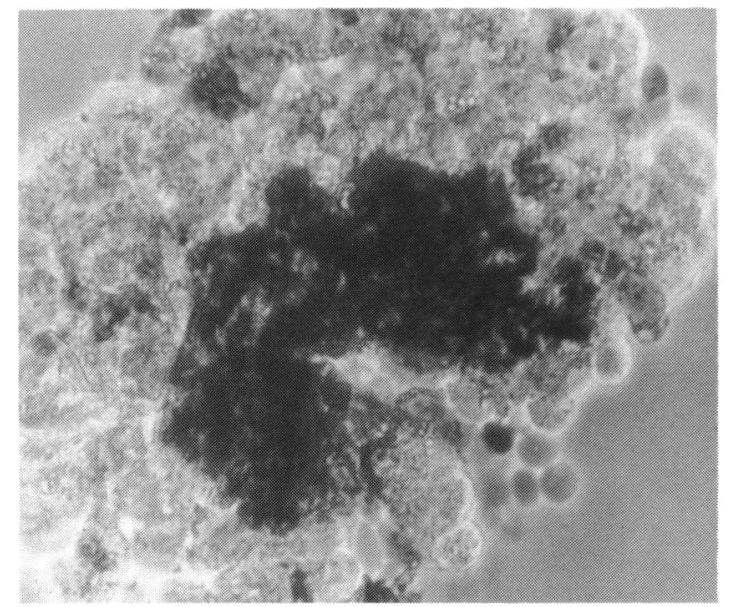

Fig. 4 Phase-contrast micrograph from a squash preparation of vitreous which was removed 4 hours after the intravitreal injection of fibroblasts. The cells are rounded and form clusters. Dead cells appear pigmented because of uptake of trypan blue. $(\times 570)$.

example, skeletal muscle, liver, kidney, stomach wall, and salivary gland - which had been frozen, sectioned and treated with the sera. ${ }^{16}$ After treatment with the sera the appropriate sections and tissues were exposed to fluorescein-labelled antihuman immunoglobulins. ${ }^{1314}$ The specimens were studied and photographed in a Zeiss epifluorescent microscope equipped with an FITC interference filter.

\section{Results}

WOUND HEALING IN THE SKIN

The fibroblasts of normal skin are scattered throughout the papillary and reticular dermis. When we examined these cells under the electron microscope they were seen to have ovoid nuclei with a prominent heterochromatin pattern, and their cytoplasm contained a few small mitochondria and poorly developed rough endoplasmic reticulum. The cytoskeletal framework of the fibroblasts consisted of a few scattered microtubules, intermediate filaments (10-12 $\mathrm{nm}$ in diameter), and contractile microfilaments 6-7 nm in diameter). Correspondingly, indirect immunofluorescent staining for 'smooth muscle' antigens in normal skin was positive in the case of vascular endothelium and epidermal keratinocytes, but was only faintly positive in the dermal connective tissue where the inactive fibroblasts (fibrocytes) were located (Fig. 1a).

During the process of wound healing the number of fibroblasts increased after the initial inflammatory episode (from day 4 onwards). From 10 to 21 days bands of elongated spindle shaped cells were prominent. Under the electron microscope the spindle shaped fibroblasts had the characteristics of actively synthesising cells, being rich in both mitochondria and rough endoplasmic reticulum. Some of the fibroblasts had distinctive bundles of microfilaments (Fig. 2) and these cells became progressively more abundant over the 10- to 21-day time period.

Consistent with this finding strongly fluorescent cells were observed in the scar tissue following treatment with 'anti-smooth muscle' sera Fig. 1b). Cells of this type have been called 'myofibroblasts' ${ }^{17-20}$ and by 4 to 5 weeks myofibroblasts were still present but were less prominent than at earlier periods.

\section{FIBROBLASTS IN CULTURE}

When the fibroblasts from the skin explants began to grow in culture they were found to have 'smooth muscle' antigens in their cytoplasm (Fig. 3). Cytoplasmic fluorescence was particularly prominent in those cells at the growing edge of the culture. Well established primary cultures and subcultures consisted of a compact mass of spindle-shaped cells, and by 3 to 4 weeks there were usually sufficient cells for intravitreal injection.

\section{CULTURED FIBROBLASTS INJECTED INTO THE} VITREOUS

Immediately after their injection into the vitreous the fibroblasts rounded up and formed clusters. These clusters persisted for at least 4 hours. After they were stained with trypan blue it was found that between 10 and $15 \%$ of the cells in the initial injections were dead. After 4 hours in the vitreous the incidence of dead cells had increased (20 to $40 \%$ ) (Fig. 4). The intact viable cells could be seen by electron microscopy to contain large numbers of lysosomal inclusions. Their cytoskeleton consisted of a few microtubules and 10 to $12 \mathrm{~nm}$ intermediate filaments. 

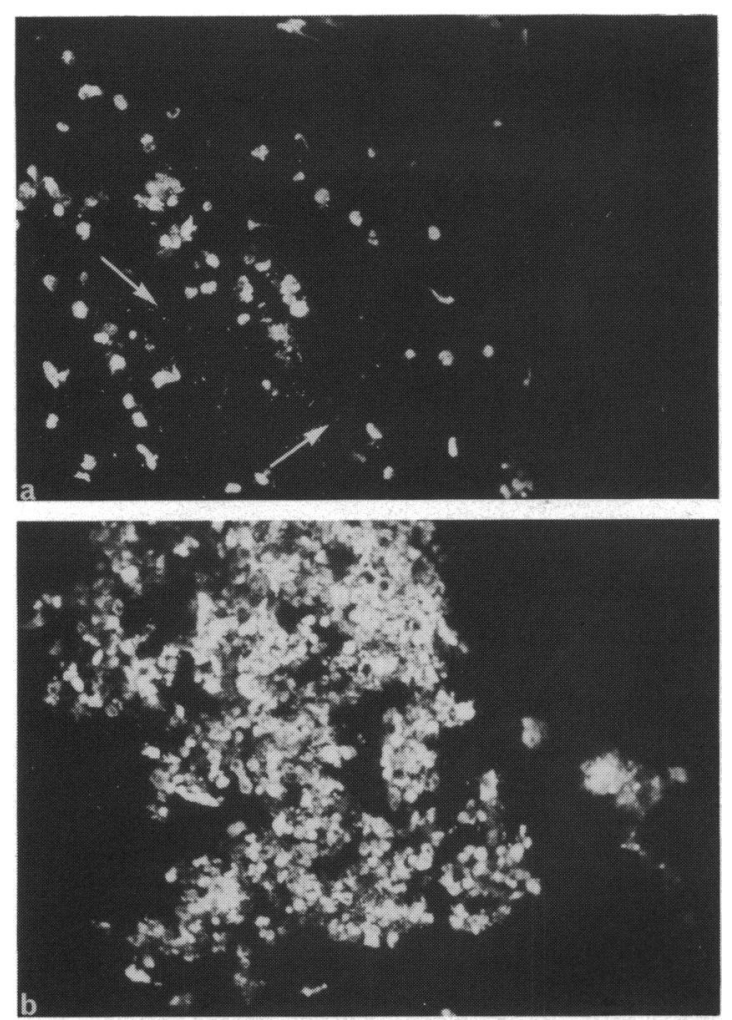

Fig. 5 Indirect immunofluorescent staining of aggregates of rounded fibroblasts 4 hours after intravitreal injection. (a) In this example scattered cells on the surface of the bolus are highly fluorescent, whereas others deeper in the bolus show little evidence of staining (arrows). (b) Another aggregate where a larger proportion of the fibroblasts are strongly fluorescent. $(\times 110)$.

Those microfilaments $(6-7 \mathrm{~nm})$ which make up the contractile system were rare and only sporadically distributed within the cell cytoplasm. Immunofluorescent studies of the intravitreal bolus 1 hour after injection showed that the bulk of the cell population were only weakly positive. However, by 4 hours some of the fibroblasts at the periphery of the aggregate had a distinct and diffuse cytoplasmic fluorescence (Fig. 5).

One day after injection into the vitreous the cells had begun to form elongated strands. By this stage most of the cells were intensely fluorescent, but the pattern was always of the diffuse form (Fig. 6). Electron microscopy showed that 6-7 nm microfilaments were common and were spread throughout the cell cytoplasm.

Between the 3rd and the 6th days the cells migrated towards the vitreous base, and the optic nerve head and sheets of cells occupied a retrolental position. During this period the cells progressively lost their
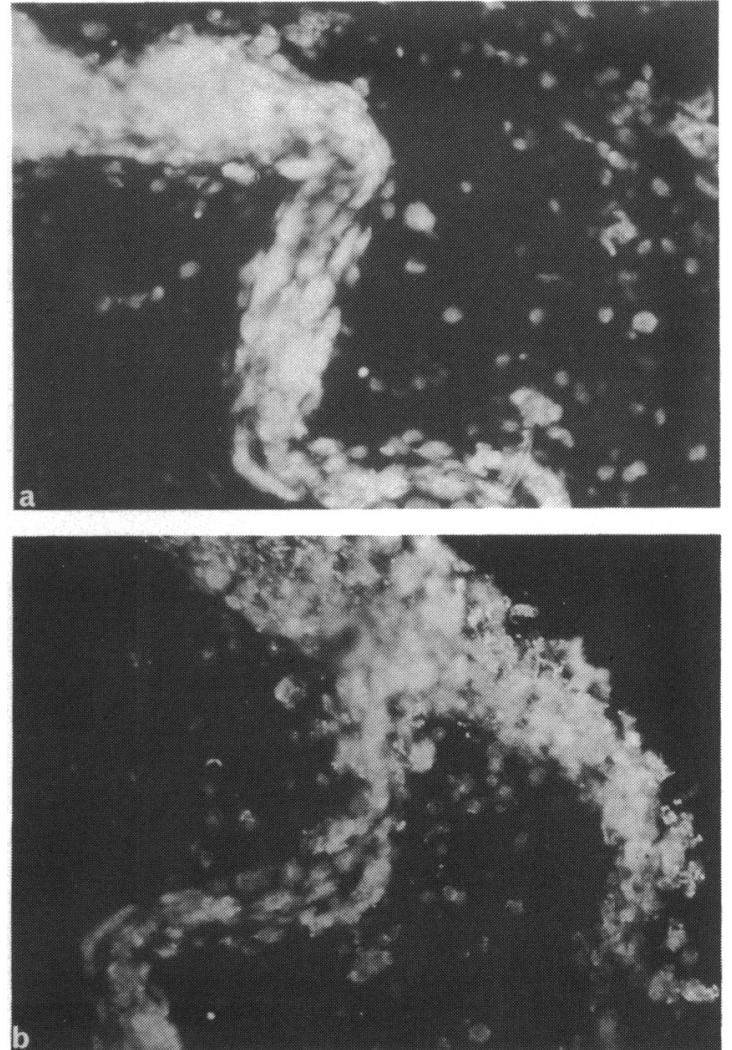

Fig. 6a, b The strands which form I day after intravitreal injection are highly fluorescent after treatment with anti-'smooth muscle' sera. $(\times 175)$.

rounded form and they adopted a more characteristic fibroblastic shape (Figs. 7 and 8). The cells had obvious 'ruffles' (Fig. 7) and filopodia (Fig. 8), both of which are features indicating cellular mobility. On day 3 microfilaments were abundant but were always diffusely spread throughout the cell cytoplasm (Fig. 9 ), whereas on day 6 we began to find cells in which the 6-7 nm microfilaments were aggregated into loose bundles (Fig. 10). Usually by the 3rd day the vitreous face was detached, and variable numbers of inflammatory cells were present. The inflammatory response became apparent on either the 1st or 2 nd day and consisted almost entirely of neutrophils. By the 6th day few neutrophils remained, and there was a predominance of lymphocytes. The lymphocytes persisted up to the 3rd week after injection.

At day 6 the fibroblasts had formed sheets throughout the vitreous (Fig. 11a). By now some of the cells appeared to be producing thin branching extracellular microfibrils (Fig. 12) and were distinguished by the presence of a well-developed Golgi system, many mitochondria, and abundant rough endoplasmic 
Fig. 7 A squash preparation of vitreal material 3 days after intravitreal injection. The fibroblasts have 'ruffles' which are a characteristic feature of their locomotion and some cells are spindle-shaped. (Phase contrast; $\times 325)$.

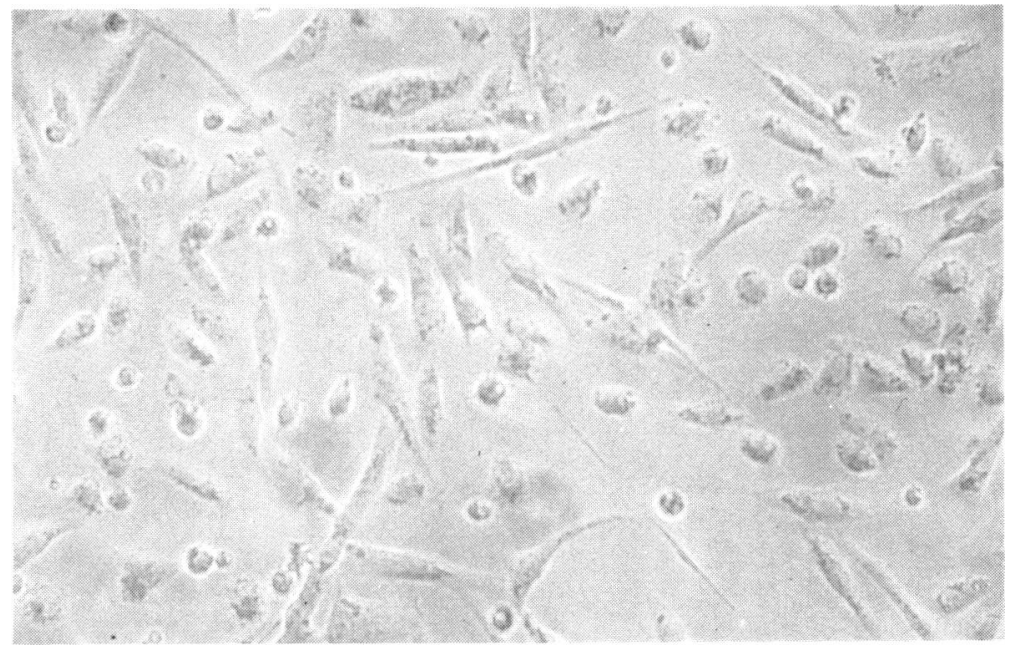

reticulum. From 6 days onwards immunofluorescent staining of the newly formed membranes gave only weakly positive results. Indeed by 2 weeks the fluorescence was so poor it was difficult to distinguish the cells.

Particularly well established membranes were found between 3 and 6 weeks, by which time retinal detachment had occurred in most eyes (Fig. 11b). Sheet-like membranes occupying an equatorial or retrolental position were common as were columnar or stalk membranes some extending between the lens and the optic nerve head. The membranes were hypercellular and the collagen within them was composed of predominantly 10 to $20 \mathrm{~nm}$ diameter fibrils which, with our staining technique, had no obvious periodicity. At the 3-week stage the fibroblasts were elongated spindle-shaped cells in close contact with each other (Fig. 13). The highly orientated bands of cells had formed gap junctions at points of cell-to-cell contact (Fig. 14). Mitochondria, Golgi vesicles, and rough endoplasmic reticulum were no longer profuse within the majority of cells. Compact bands of microfilaments were a frequent finding and these aggregates were located in the cytoplasm immediately beneath the plasma membrane (Fig. 15). Similar bands of closely associated microfilaments have been observed in a variety of cells in vitro and have been called 'stress-cables' (see discussion). Occasionally the 'stress-cables' extended into thin cytoplasmic processes to constitute microtendons (Fig. 15) that either joined neighbouring cells or were embedded in the extracellular matrix. Some of the cells in the membranes had heavily indented nuclei (Fig. 13), but otherwise the nuclei were unremarkable.

Immunofluorescent staining showed fine fluor-

Fig. 8 An electron micrograph of a fibroblast 6 days after intravitreal injection. The cell has numerous filopodia and a more characteristic fibroblastic shape. (Uranyl acetate/lead citrate staining; $\times$ 3950).

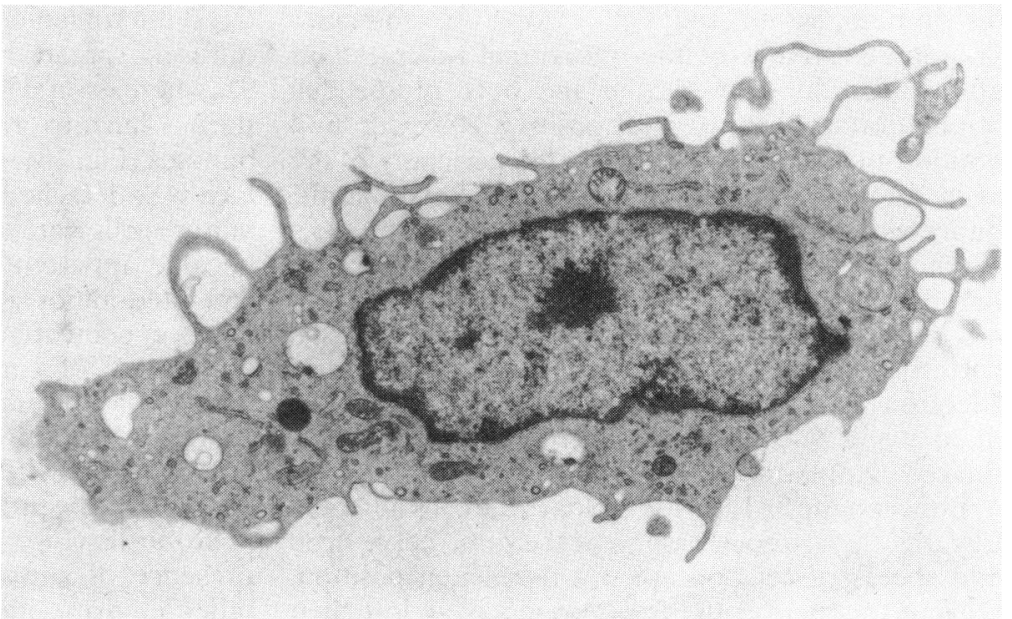



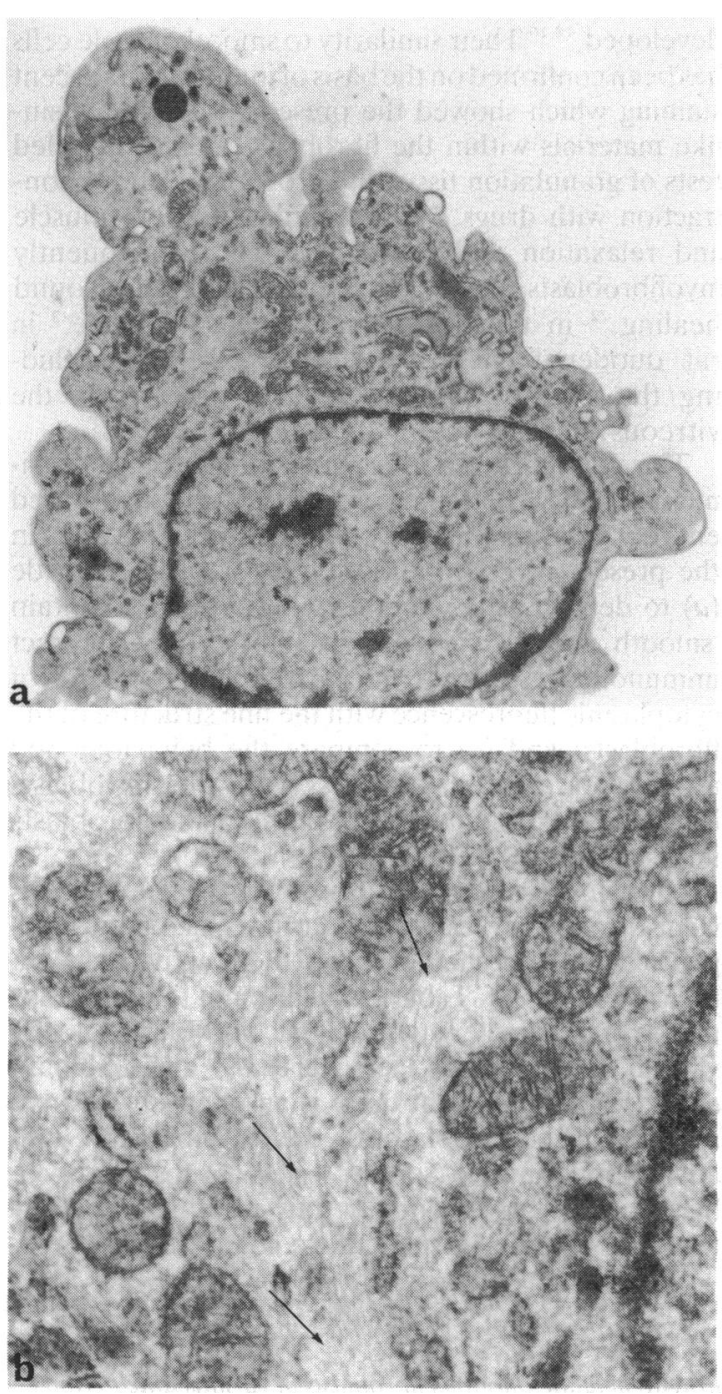

Fig. 9 (a) An electron micrograph of a fibroblast 3 days after injection. Portion of the cell is shown at higher magnification in b. (b) The arrows indicate 6-7 nm microfilaments diffusely spread throughout the cytoplasm. (Uranyl acetate/lead citrate staining; (a) $\times 4530$; (b) $\times 28300)$.

escent streaks within the cells which we considered to correspond to the 'stress-cables' seen by electron microscopy (Figs. 16 and 17). At higher magnification of individual cells the evidence was even more compelling. The overall cytoplasmic fluorescence was weak except for the strands of intense fluorescence (Fig. 18).

With our long-term survival experiments ( 10 weeks to 6 months) the membranes became progressively richer in their collagen content and fibroblasts

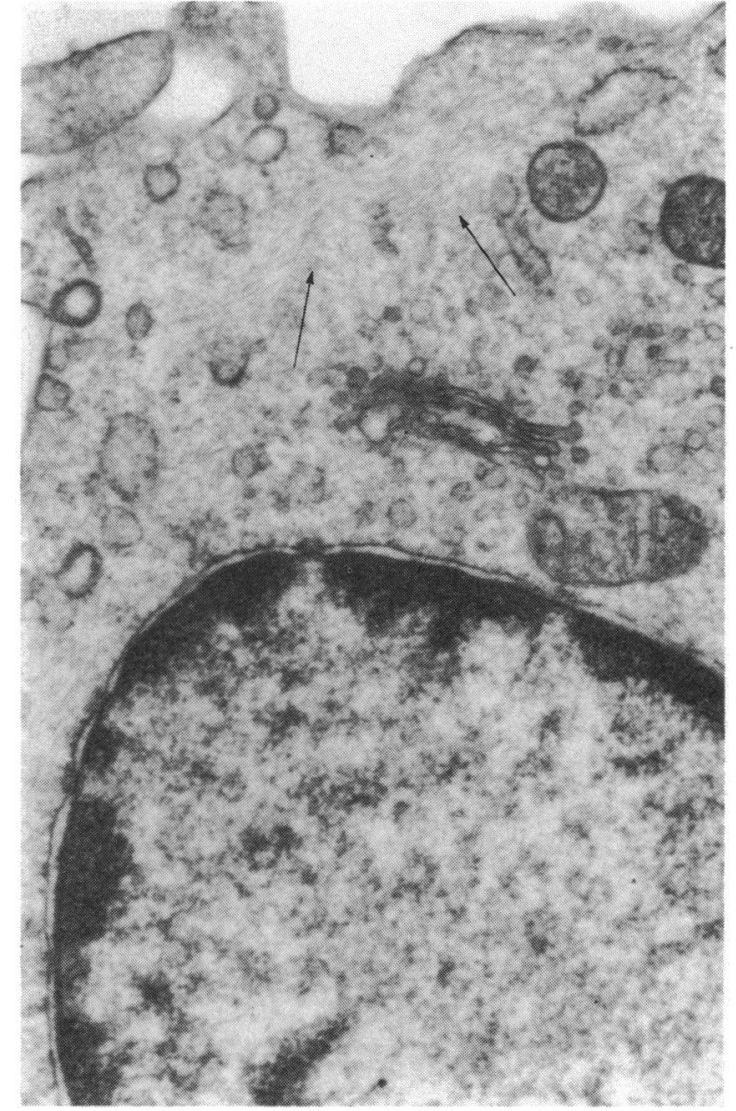

Fig. 10 An electron micrograph of part of an intravitreal fibroblast 6 days after injection. A bundle of 6-7 $\mathrm{nm}$ microfilaments are indicated by arrows. (Uranyl acetate/lead citrate staining; $\times 23860$ ).

became less abundant (Fig. 19). The cells at the centre of these dense membranes showed evidence of lipoidal degeneration (Fig. 19). Although 10-20 nm unbanded collagen fibrils were much in evidence larger diameter, banded fibrils had become components of the matrix. Collagen fibrils of 30 to $45 \mathrm{~nm}$ diameter with a periodicity of about $40 \mathrm{~nm}$ were common, but also $80 \mathrm{~nm}$ diameter fibrils with a 62 to $64 \mathrm{~nm}$ periodicity were found.

\section{Discussion}

The term 'myofibroblast' was coined by several authors ${ }^{17-20}$ to describe a type of fibroblast seen in granulation tissue which has many of the features of the smooth muscle cell but few of the characteristics of the classical fibroblast. These cells have abundant intracytoplasmic microfilaments whereas the rough endoplasmic reticulum and mitochondria are poorly 

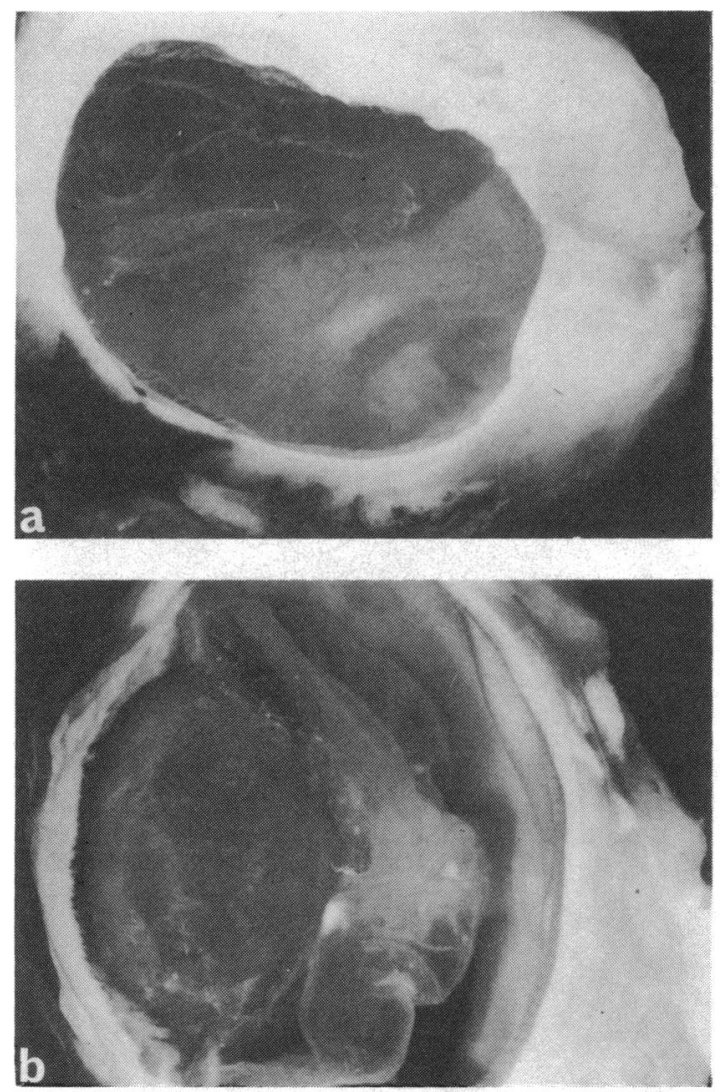

Fig. 11 (a) A macrophotograph showing membranous sheets throughout the vitreous 6 days after injection. (b) $A$ macrophotograph of an eye enucleated 6 weeks after intravitreal injection of fibroblasts. Retinal detachment is evident. developed. ${ }^{1820}$ Their similarity to smooth muscle cells has been confirmed on the basis of immunofluorescent staining which showed the presence of actomyosinlike materials within the fibroblasts. ${ }^{21}$ Also detailed tests of granulation tissue in vitro ${ }^{17} 18$ has shown contraction with drugs which stimulate smooth muscle and relaxation with relaxant drugs. Subsequently myofibroblasts have been identified in wound healing, ${ }^{22}$ in the normal rat testicular capsule ${ }^{23}$ in rat duodenal villi ${ }^{24}$ and many other sites including the fibrous membranes which develop in the vitreous. ${ }^{23}$

The identification of myofibroblasts in experimental fibrous vitreal membranes has been based entirely on ultrastructural observations, ${ }^{23}$ whereas in the present investigation attempts have been made (a) to determine whether vitreal fibroblasts contain 'smooth muscle' elements as indicated by indirect immunofluorescence; $(b)$ to correlate the patterns of cytoplasmic fluorescence with the fine structure of the fibroblasts; and $(c)$ to compare the behaviour and ultrastructural characteristics with the fibroblasts involved in wound healing of the skin and fibroblasts in tissue culture.

It was evident that the fibroblasts in the vitreous went through several stages during which their morphology and presumably also their activities were radically different. Table 1 is an attempt to summarise the main characteristics of the fibroblasts at the various time intervals. Herschel et al. ${ }^{21}$ and Gabbiani et al. ${ }^{18}$ have found that there is an intensely positive reaction in the cytoplasm of the myofibroblast with anti-smooth muscle serum, whereas normal fibroblasts are negative. Equally they were able to show that fibroblasts in tissue culture could adopt a myo-

Table 1 Summary table showing the main characteristics of intravitreal autochthonous fibroblasts at various time periods

\begin{tabular}{|c|c|c|c|c|c|c|c|}
\hline Time period & Activities & Membrane & $\begin{array}{l}\text { General } \\
\text { appearance }\end{array}$ & $\begin{array}{l}\text { Morphological } \\
\text { characteristics }\end{array}$ & Immunofluorescence & $\begin{array}{l}\text { Immunofluorescence } \\
\text { pattern }\end{array}$ & $\begin{array}{l}\text { General } \\
\text { comments }\end{array}$ \\
\hline $0-1$ days & Quiescence & Bolus of cells & Rounded & $\begin{array}{l}\text { Large nuclear to } \\
\text { cytoplasmic ratio }\end{array}$ & Weak & Diffuse & $\begin{array}{l}\text { Inflammatory } \\
\text { response after } 1 \text { day }\end{array}$ \\
\hline $2-4$ days & Motility & Strands of cells & $\begin{array}{l}\text { Intermediate } \\
\text { form }\end{array}$ & $\begin{array}{l}\text { Decreased nuclear to } \\
\text { cytoplasmic ratio, cells } \\
\text { have microvilli }\end{array}$ & Strong & Diffuse & $\begin{array}{l}\text { Detached vitreous } \\
\text { face }\end{array}$ \\
\hline $\begin{array}{l}6 \text { days to } \\
2 \mathrm{wks}\end{array}$ & Synthesis & $\begin{array}{l}\text { Membrane } \\
\text { sheets }\end{array}$ & $\begin{array}{l}\text { Typical } \\
\text { fibroblastic } \\
\text { form }\end{array}$ & $\begin{array}{l}\text { Large quantities of } \\
\text { r.e.r., many } \\
\text { mitochondria, well } \\
\text { developed golgi }\end{array}$ & Moderate to weak & Reticular & Liquefied vitreous \\
\hline $\begin{array}{l}3 \text { wks to } \\
10 \text { wks }\end{array}$ & Contraction & $\begin{array}{l}\text { Retrolental. } \\
\text { equatorial, stalk } \\
\text { membranes }\end{array}$ & $\begin{array}{l}\text { Thin elongated } \\
\text { spindle shape }\end{array}$ & $\begin{array}{l}\text { Aggregates of } \\
\text { microfilaments within } \\
\text { the cells } \\
\text { Some nuclei are crenated } \\
\text { gap junctions have } \\
\text { formed }\end{array}$ & Moderate & Stress cables & $\begin{array}{l}\text { Retinal detachment } \\
\text { has taken place }\end{array}$ \\
\hline $\begin{array}{l}10 \text { wks to } \\
6 \text { mths }\end{array}$ & $\begin{array}{l}\text { Remodelling and } \\
\text { maturation (fixed } \\
\text { scar) }\end{array}$ & $"$ & $\begin{array}{l}\text { Elongated } \\
\text { irregular }\end{array}$ & $\begin{array}{l}\text { Large accumulations of } \\
\text { lipid within some cells }\end{array}$ & $"$ & Mixed & $\begin{array}{l}\text { Neovascularisation, } \\
\text { epiretinal glial } \\
\text { proliferation may } \\
\text { have taken place }\end{array}$ \\
\hline
\end{tabular}


fibroblast form. ${ }^{25}$ Indeed it is well known that cultured fibroblasts contain contractile proteins within their cytoplasm, ${ }^{26}$ and immunofluorescence studies on our cultured cells confirmed this finding.

After injection into the vitreous, however, the cells contained few contractile microfilaments, and staining with sera rich in 'smooth muscle' antibodies gave only weakly positive results. It was an extremely interesting finding that in the vitreous the most intense reaction was not with the so-called myofibroblasts but at the earlier presynthesis motile stage when a strongly positive diffuse cytoplasmic staining reaction was observed. In this particular model our immunofluorescent and ultrastructural studies indicate that, as traction membranes develop, there is not so much an overall increase in the contractile elements of the constituent cells as a rearrangement of the microfilaments into compact highly organised bundles orientated parallel to the long axis of the cell. The characteristics of the myofibroblasts in the vitreous are $(a)$ they are not rich in rough endoplasmic reticulum and mitochondria; $(b)$ they are elongated spindle shaped cells; $(c)$ they form compact
Table 2 A comparison of the main features of skin and vitreal myofibroblasts. The characteristics of skin myofibroblasts are based on our own observations and the findings of Ryan et al.,${ }^{19}$ Montandon et al. ${ }^{20}$ Gorgas and Böck, ${ }^{23}$ and Gabbiani et al. ${ }^{25}$

\begin{tabular}{|c|c|c|}
\hline Features & \multirow{2}{*}{$\begin{array}{l}\text { Skin } \\
\text { myofibroblasts }\end{array}$} & \multirow{2}{*}{$\begin{array}{l}\begin{array}{l}\text { Vitreal } \\
\text { myofibroblasts }\end{array} \\
++\end{array}$} \\
\hline $\begin{array}{l}\text { 1. Microfilaments (dispersed throughout } \\
\text { the cytoplasm) }\end{array}$ & & \\
\hline 2. Microfilaments (forming stress cables) & $+t+$ & +++ \\
\hline 3. Dense bodies & +++ & + \\
\hline 4. Microtendons & $+t+$ & +++ \\
\hline 5. Indented nuclei & +++ & +++ \\
\hline 6. Gap junctions & $+t+$ & ++ \\
\hline 7. Desmosomes (Maculae adhaerentes) & +++ & + \\
\hline 8. Hemidesmosomes & ++ & \\
\hline
\end{tabular}

Kev: $+++=$ Abundant: $++=$ common: $+=$ rare.

sheets; $(d)$ gap junctions link adjacent cells; $(e)$ some cells have highly invaginated nuclei; $(f)$ microtendons are frequently evident; and $(g)$ the contractile filaments are arranged into thick bundles of 6 to $7 \mathrm{~nm}$ microfilaments.

Myofibroblasts elsewhere in the body have the

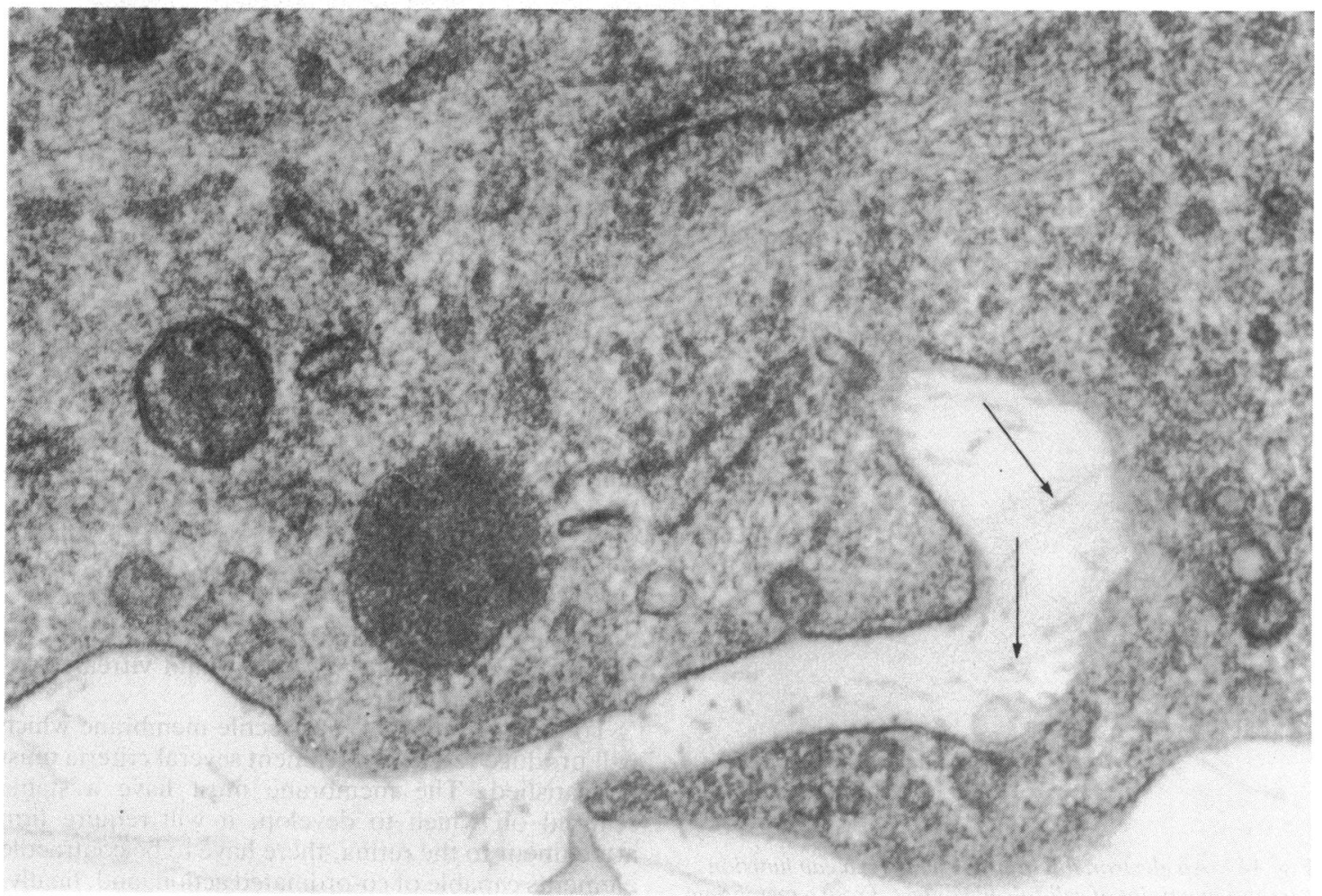

Fig. 12 An electron micrograph showing part of an intravitreal fibroblast 6 days after injection. Thin branching extracellular microfibrils (arrows) are seen to be in intimate association with the plasma membrane. (Uranyl acetate/lead citrate section staining; $\times 60000)$. 
Fig. 13 Electron micrographs of membranes at 3 weeks. (a) The membrane is hypercellular consisting of connecting spindle-shaped cells. Attachments between cells are by thin elongated processes. (b) A similar membrane to that in a. The nuclei (n) have many infoldings. (Uranyl acetate and lead citrate staining; $\times 4230)$.
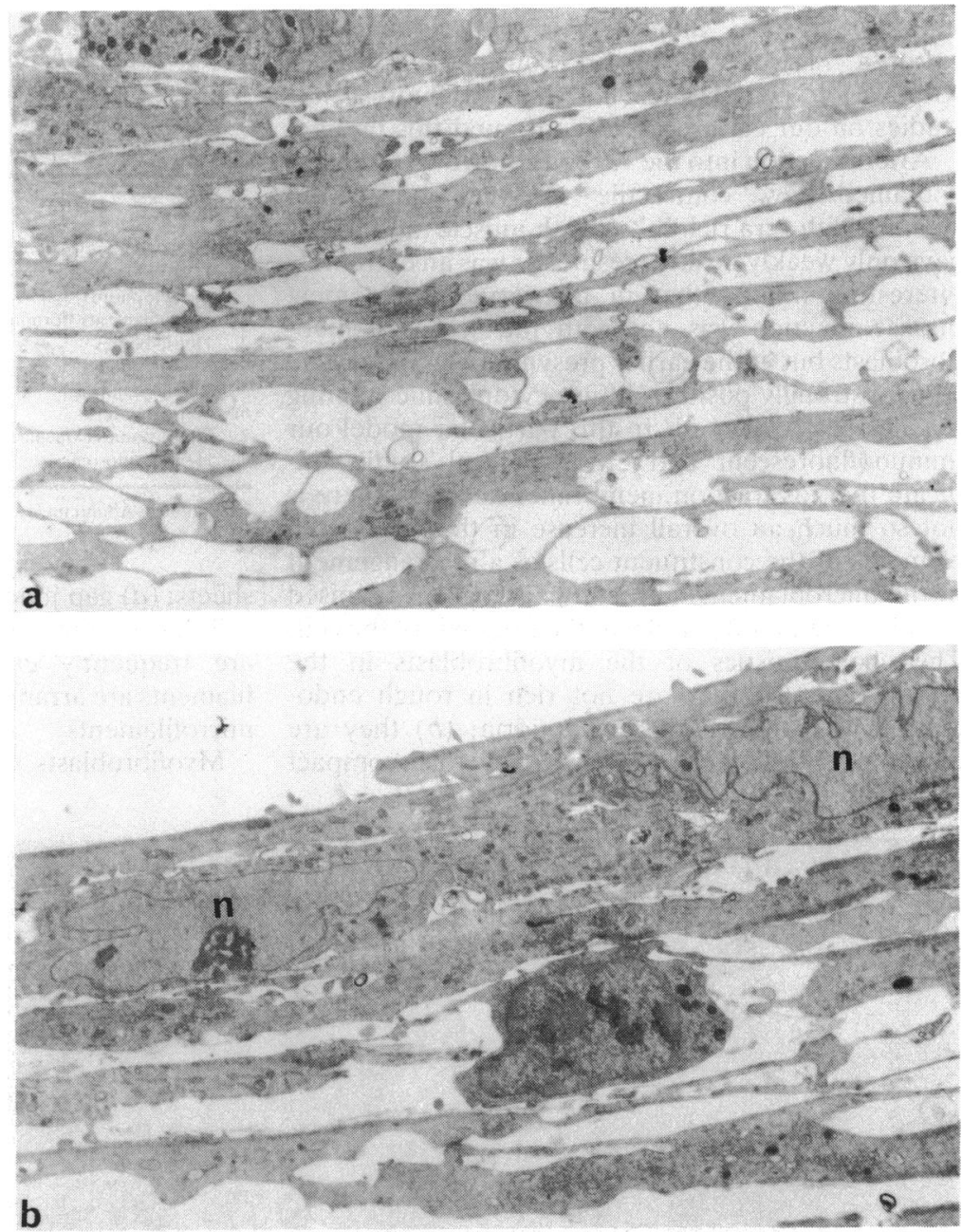

Fig. 14 An electron micrograph showing a gap junction (arrow) at a point of cell-to-cell contact. From a membrane which has formed 6 weeks after the injection of fibroblasts into the vitreous. (Uranyl acetate/lead citrate staining; $\times 27500)$. features we have described but in addition 'dense bodies, ${ }^{19}$ maculae adhaerentes, and hemidesmosomes ${ }^{20}$ have been noted. We have seen all 3 in our cells, but they were not particularly prominent and certainly were too rare to be considered as distinguishing features of the vitreal myofibroblasts. In Table 2 the main features of skin and vitreal myofibroblasts are compared.

To have an effective contractile membrane which will produce retinal detachment several criteria must be satisfied. The membrane must have a stable scaffold on which to develop, it will require firm attachment to the retina, there have to be contractile elements capable of co-ordinated action, and, finally, the contractile elements (myofibroblasts) must be firmly adherent to the scaffold.

As yet we know little about the adhesion of the 

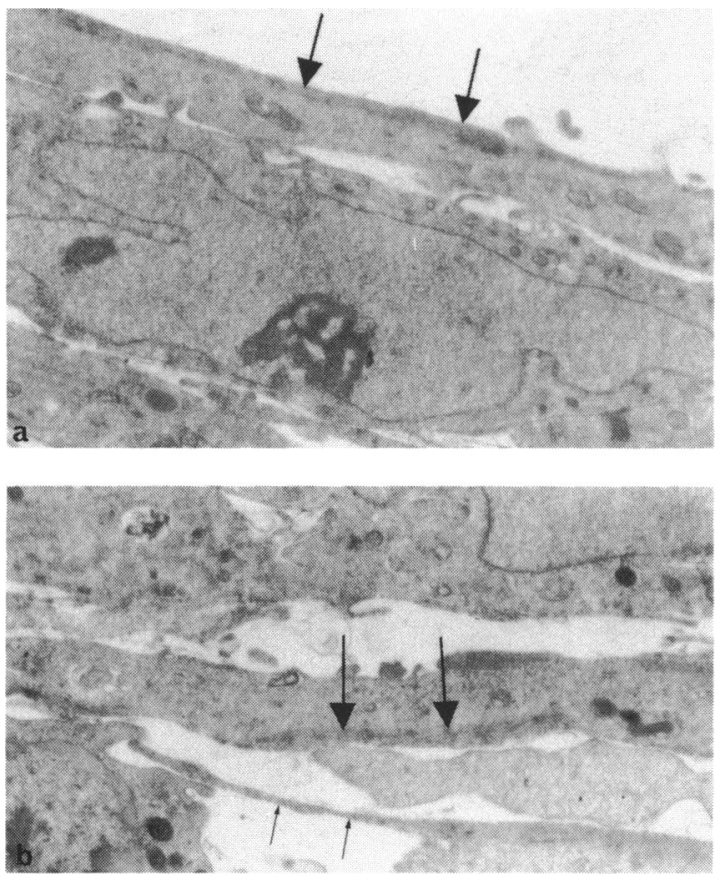

Fig. 15 Higher power electron micrographs of areas shown in Fig. 13b. (a) A stress-cable of compact microfilaments is indicated by arrows. (b) $A$ stress-cable (large arrows) and a microtendon (small arrows) can be seen. (Uranyl acetate/lead citrate staining; $\times 8700$ ).

myofibroblasts to their collagen scaffold. Hemidesmosomes usually have a prominent role in cell to extracellular matrix associations but unlike other

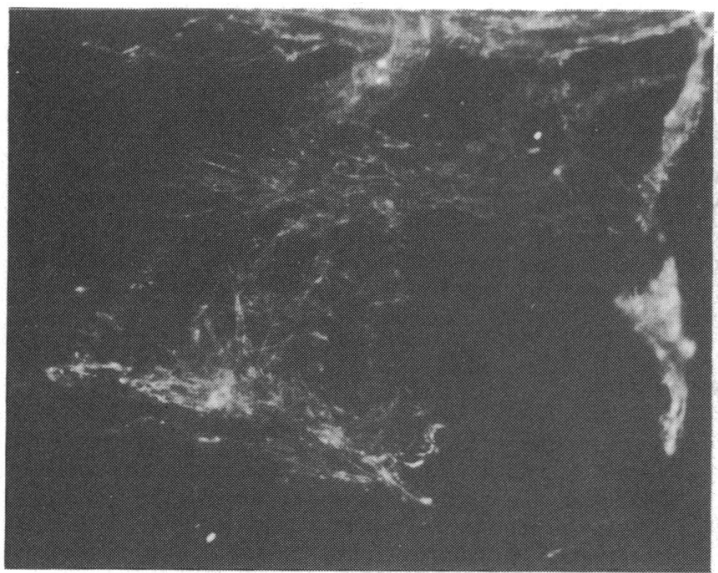

Fig. 16 Indirect immunofluorescent staining with sera rich in anti-'smooth muscle' antibodies of a sheet membrane 3 weeks after the injection of fibroblasts into the vitreous. Streaks of positive staining corresponding to 'stress-cables' can be identified $(\times 200)$. tissues where myofibroblasts abound ${ }^{2022} 23$ we were unable to find significant numbers of attachment zones. Our evidence that the fibroblasts are the contractile elements is indirect but compelling. The fibroblasts are organised into sheets and have linking gap junctions. Gap junctions are thought to be coupling devices and serve as low resistance pathways by which ions and metabolites can pass between cells. ${ }^{27}$ Thus the fibroblasts have the necessary attachments for co-ordinated action. Bundles of microfilaments usually considered to be rich in actin are present within the fibroblasts, and by immunofluorescence these bundles have been shown to selectively bind sera rich in anti-'smooth muscle' antibodies. Thus, having the necessary contractile apparatus, the indentation of the cell nuclei is an indication that contraction may have taken place. ${ }^{28}$ The nuclei of smooth muscle cells, ${ }^{29}$ vascular endothelia, ${ }^{28}$ and heart muscle cells ${ }^{30}$ show a similar pattern of deep infoldings and multiple indentations during contraction. Obviously it is important to undertake a pharmacological study of the effects on the fibrous membranes of drugs which can produce relaxation and contraction of smooth muscle.

It should not be considered that the fibroblast is unique in its ability to adopt a different arrangement of its contractile proteins in response to external stimuli. Many cells can do this both in vivo and vitro, ${ }^{131426}$ although perhaps not in quite such a spectacular manner. During locomotion the microfilaments of the mobile cell are dispersed throughout the cytoplasm and appear to be arranged in a haphazard manner. On the other hand the so-called stress-fibres or organised bundles of microfilaments

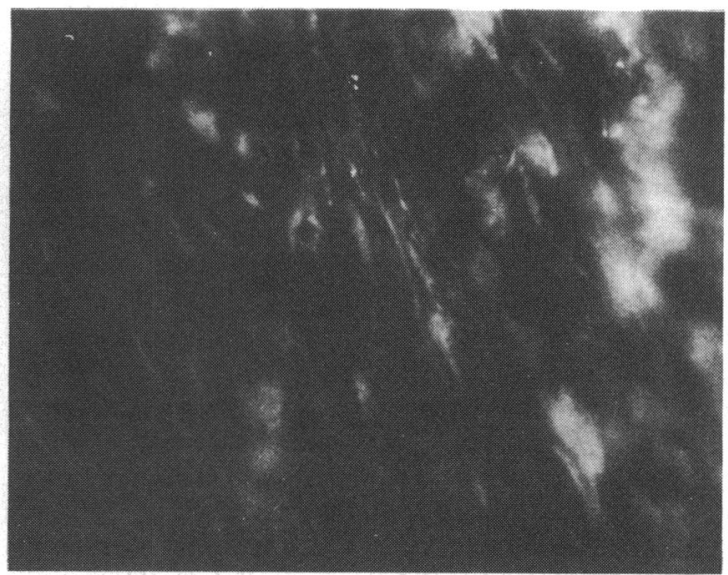

Fig. 17 Indirect immunofluorescent staining with sera rich in anti-'smooth muscle' antibodies of a membrane 6 weeks after the injection of fibroblasts into the vitreous. Stress-cables can be seen $(\times 275)$. 


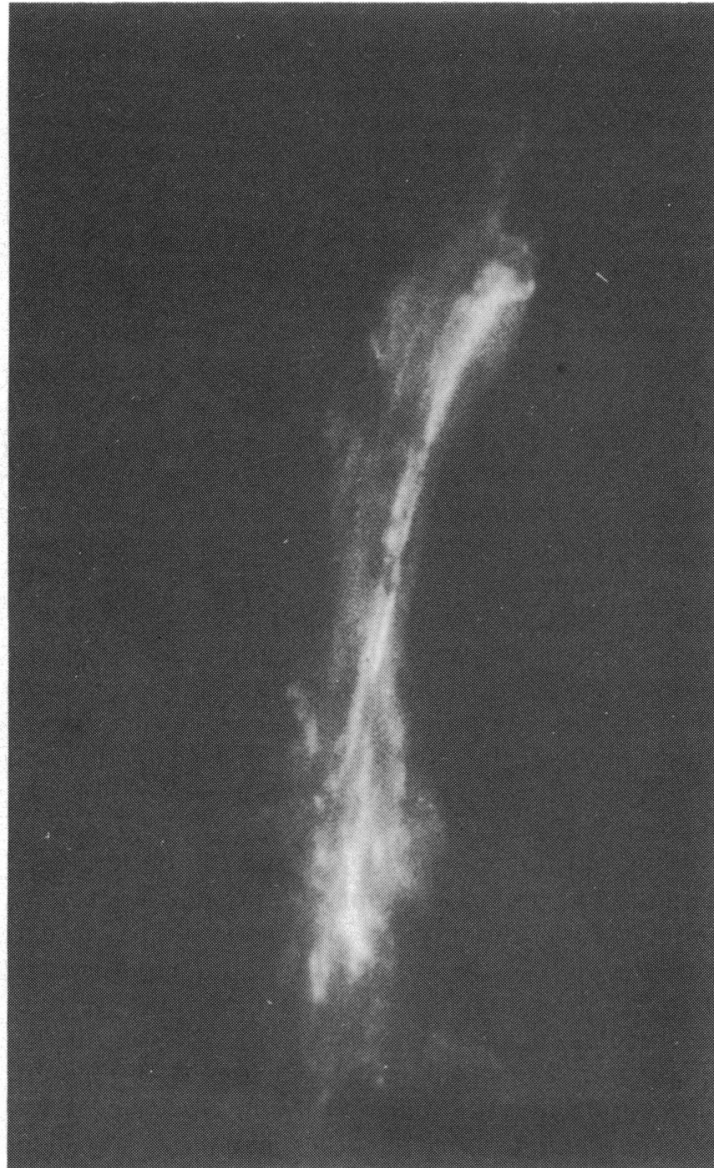

Fig. 18 A cell at the periphery of a 6-week intravitreal membrane treated with sera rich in anti-'smooth muscle' antibodies. The overall cytoplasmic fluorescence is poor except for a distinctive strand of fluorescence which probably corresponds to the 'stress-cables' seen in the electron micrographs. $(\times 1000)$.

are associated with cells which are anchored firmly to a substrate. ${ }^{2631}$ Whether the prominent actin-rich microfilamentous bundles in the cytoplasm of myofibroblasts merely bind the cells to the collagenous scaffold or are the contractile system responsible for retinal detachment remains to be established.

It has been proposed that collagen formation is the basis of the contraction of fibrous membranes, ${ }^{132}$ but normal collagen does not contract and as $w^{3}$ and others ${ }^{2}$ have shown the basis of membrane retraction is cellular rather than extracellular. However, maturation of the extracellular matrix from the thin unbanded microfibrils which initially were the sole components of the scaffold to the complex of unbanded and banded collagen microfibrils (seen at 10
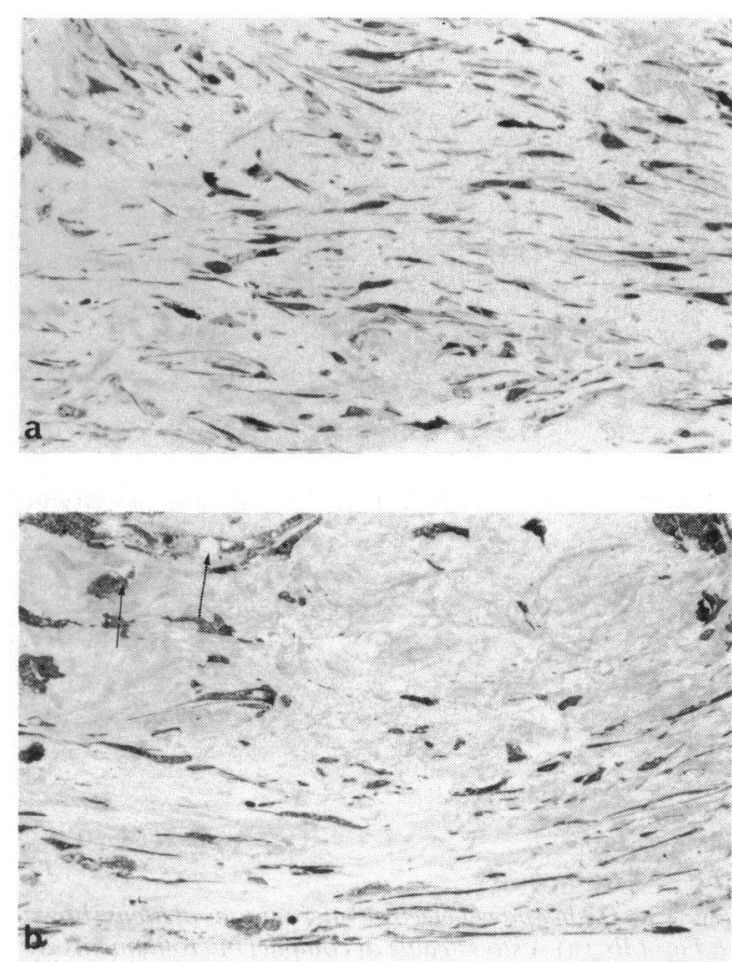

Fig. 19 Light micrographs of toluidine blue stained semithin sections through parts of membranes 3 months after the injection of fibroblasts. (a) There is a well developed extracellular matrix in the long-term membranes. (b) In addition the cells in the middle of these membranes show evidence of lipoidal degeneration (arrows). $(\times 350)$.

weeks) may be the locking mechanism whereby the contracted membrane develops into a fixed scar. The processes involved have been studied in wound healing of the $\operatorname{skin}^{33}$ but they remain an important area for future research in vitreal fibrosis.

We acknowledge with thanks the advice and comments of Mr D. McLeod. Moorfields Eye Hospital, and Professor A. Garner. Department of Pathology. Institute of Ophthalmology. London. We also thank Miss E. Robins. Mr R. C. Howes. Mr S. Ahmed, and Miss L. Millar for their technical assistance. The secretarial help was provided by Miss L. S. Hart.

\section{References}

1 Algvere P, Kock E. Experimental fibroplasia in the rabbit vitreous. Retinal detachment induced by autologous fibroblasts. Albrecht von Graefes Arch Klin Ophthalmol 1976; 199: 215-22.

2 Sugita G, Tano Y, Machemer R, Abrams G. Claflin AJ. Fiorentino G. Intravitreal autotransplantation of fibroblasts. Am J Ophthalmol 1980; 89: 121-30.

3 Grierson I, Forrester JV. Vitreous haemorrhage and vitreal membranes. Trans Ophthalmol Soc UK 1980; 100: 40-50.

4 Constable IJ, Pathology of vitreous membranes and the effect of haemorrhage and new vessels on the vitreous. Trans Ophthalmol Soc UK 1975; 95: 382-6. 
5 Faulborn J. Topping TM. Proliferation in the vitreous cavity after perforating injuries: a histopathologic study. Albrecht von Graefes Arch Klin Ophthalmol 1978; 205: 157-66.

6 Winthrop SR. Cleary PE. Minckler DS. Ryan SJ. Penetrating eye injuries: a histopathological review. Br J Ophthalmol 1980; 64: 809-17.

7 Machemer R. Aaberg TM. Vitrectomy. 2nd ed. New York. San Francisco. London: Grune and Stratton. 1979.

8 Coles WH. Haik GM. Vitrectomy intraocular trauma. Its rationale and its indications and limitations. Arch Ophthalmol 1972; 87: 621-8.

9 Machemer R. Massive periretinal proliferation. A logical approach to therapy. Trans Am Ophthalmol Soc 1977: 75: 556-86.

10 Tripathi B. Retinal vascular complex of rabbit and its response to hyperoxia in tissue culture. PhD Thesis, London University. 1971.

11 Grierson I. Robins E. Howes RC. Preliminary observations on human trabecular meshwork cells in vitro. Albrecht von Graefes Arch Klin Ophthalmol 1980; 212: 173-86.

12 Forrester JV. Grierson I. The cellular response to blood in the vitreous, an ultrastructural study. J Pathol 1979; 129: 43-52.

13 Rahi A. Grierson I. Ashton N. Contractile proteins in ocular tissues: role in health and disease. Trans Ophthalmol Soc UK 1980; 100: $155-61$.

14 Rahi A. Ashton N. Contractile proteins in retinal endothelium and other non-muscle tissues of the eye. Br J Ophthalmol 1978; 62: $627-43$.

15 Grierson I, Rahi AHS. Microfilaments in the cells of the human trabecular meshwork. Br J Ophthalmol 1979; 63: 3-8.

16 Trenchev $P$. Holborow EJ. The specificity of anti-actin serum. Immunologv 1976: 31: 509-17.

17 Majno G. Gabbiani G. Hirschel BJ, Ryan GB. Statkov PR. Contraction of granulation tissue in vitro: similarity to smooth muscle. Science 1971: 173: 548-9.

18 Gabbiani G, Herschel BJ. Ryan GB. Statkov PR. Majno G. Granulation tissue as a contractile organ. A study of structure and function. J Exp Med 1972; 135: 719-34.
19 Ryan GB. Cliff WJ, Gabbiani G. et al. Myofibroblasts in human granulation tissue. Human Pathol 1974; 5: 55-67.

20 Montandon D, Gabbiani G. Ryan GB. Majno G. The contractile fibroblast. Its relevance in plastic surgery. Plast Reconstr Surg 1973: 52: 286-92.

21 Herschel BJ, Gabbiani G. Ryan GB, Majno G. Fibroblasts of granulation tissue: immunofluorescent staining witb anti-smooth muscle serum. Proc Soc Exp Biol Med 1971; 138: 466-9.

22 Squier CA. Kremenak CR. Myofibroblasts in healing palatal wounds of the beagle dog. J Anat 1980; 130: 585-94.

23 Gorgas K. Böck P. Myofibroblasts in the rat testicular capsule. Cell Tissue Res 1974; 154: 533-41.

24 Guldner FH. Wolff JR. Keyserlingk DG. Fibroblasts as a part of the contractile system in duodenal villi of rat. $Z$ Zellforsch Mikrosk Anat 1972: 135: 349-53.

25 Gabbiani G. Majno G. Ryan GB. The fibroblast as a contractile cell. The myofibroblast. In: Pikkarainen J, Kulonen K. eds. Biology of the Fibroblast. New York: Academic Press. 1973: 139-54.

26 Lazarides E. Immunofluorescence studies on the structure of actin filaments in tissue culture cells $J$ Histochem Cytochem 1975; 23: $507-28$.

27 Gilula NB. Reeves OR. Steinbach A. Metabolic coupling and cell contacts. Nature 1972; 235: 262-5.

28 Majno G. Shea SM. Leventhal M. Endothelial contraction induced by histamine-type mediators. An electron microscopic study. J Cell Biol 1969; 42: 647-72.

29 Lane BP. Alterations in the cytologic detail of intestinal smooth muscle in various stages of contraction. J Cell Biol 1965; 27: 199-213.

30 Bloom S. Cancilla PA. Conformational changes in myocardial nuclei of rats. Circ Res 1969;24: 189-96.

31 Pollack R. Rifkin D. Actin-containing cables within anchorage dependent rat embryo cells are dissociated by plasma and trypsin. Cell 1975; 6: 495-506.

32 Havener WH. Massive vitreous retraction. Ophthalmic Surg 1973; 4: 22-67.

33 Rudolph R. Guber S. Suzuki M. Woodward M. The life cycle of the myofibroblast. Surg Gynecol Obstet 1977; 145: 389-94. 